\title{
GENETIC DIVERSITY ASSESSMENT OF NEEM (Azadirachta indica A. Juss) IN NORTHERN NIGERIA
}

\author{
Barka P. MSHELMBULA ${ }^{1,2}$, Geoffrey O. ANOLIEFO ${ }^{2}$, Beckley IKHAJIAGBE ${ }^{2,3,4,5}$ and Boniface 0. \\ EDEGBAI ${ }^{2}$
}

${ }^{1}$ Department of Plant Science and Biotechnology, Federal University of Lafia, PMB 146, Lafia, Nigeria.

${ }^{2}$ Environmental Biotechnology and Sustainability Research Group, Dept. of Plant Biology and Biotechnology, University of Benin, Benin City, Nigeria.

${ }^{3}$ Applied Environmental Biosciences and Public Health Research Group, Department of Microbiology, University of Benin, Benin City, Nigeria.

${ }^{4}$ Corresponding author: beckley.ikhajiagbe@uniben.edu

${ }^{5}$ ORCID: https://orcid.org/0000-0003-2834-7447.

\begin{abstract}
Neem is a tropical tree that can adapt to a wide range of places and particularly to semi- arid conditions. As at present, it is grown in many Asian countries and also in the tropical regions of the western hemisphere. Genetic variability and diversity are a major requirement needed for both immediate results and the one ones thereafter adaptation of plant types in their original domain. The evaluation of genetic diversity of any species is extremely crucial for their sustainability, continuity, survival and gene manipulation. Major breakthroughs in the field of molecular biology was able to develop several tools for the investigation of genetic diversity at the genome level to determine phylogenetic relationships among inter or intraspecies. The advent of molecular markers for the detection and exploitation of DNA polymorphism is one of the major breakthroughs in the world of molecular genetics.

The importance of genetic diversity in plant germplasm conservation, especially in economically important species such as Azadirachtaindica, is enormous, particularly in Nigeria. The question is whether A. indica from different Agro-ecological zones have genetic variations or similarities. This was the bane of the current study, which used RAPD to look atgenetic diversity of 27 randomly selected neem trees within the agro-ecological zones in Northern Nigeria. A total of 9 primers were employed out of which only 5 were responsive (OPA-02, OPA-03, OPA-15 and OPA-19). These primers showed dissimilarities in the visible DNA bands among the various tree samples. There was evidence of genetic dissimilarities among the trees sampled. Differences in percentage polymorphism was reported, where it was reportedly highest among the Borno State tree samples $(97.44 \%)$, compared to those in Yobe State with no polymorphism.
\end{abstract}

Keywords: neem, molecular characterization, heritability, genetic gain, Azadirachtaindica

\section{Introduction}

Azadirachtaindica A. Juss (Meliaceae) is a well adaptable plant that lives in forests where agriculture is practiced of the semiarid and arid tropics, and is native to the dry forest zones of Asia (Koulet al. 1990, Ketkar and Ketkar 1995). It is widely distributed, and this may be the result of its wide acceptability, particularly for its economic importance.Neem trees have been broadly developed within the tropics. Its seedlings are raised in the nursery from where they are transplanted unto the field. It is a tree in Northern Nigeria that is almost synonymous with the term "tree of life". This is so because there is virtually hardly any man-made settlement without the neem tree. It flourishes in nutrient-poor dry soils and is tolerant of temperatures when high but is vulnerable to over the top cold or ice. It has uses in ethno 
medicine, construction, energy and fuel, environmental protection, traditional significance, fencing and agricultural intervention. Neem trees have been broadly developed within the tropics. Its seedlings are often grown in the nursery and later raised in the field.

Due to the cosmopolitan nature of the tree, it may be exposed to a wide range of environments and ecosystems, particularly since it has been connected to nearly every agroecological zone in Nigeria.It's unclear if this ability is inherited or provides genetic diversification. Genetic diversity is an essential factor in species stability in any ecosystem, as it provides important transformations to the dominant biotic and abiotic natural conditions, as well as allowing changes in genetic make-up to adapt to changes in the environment.

The assessment of hereditary difference of any species is extremely crucial for their preservation and gene improvement (Khan et al. 2012). The objective of this study is to evaluate the genetic variability among individual neem species using Randomly Amplified Polymorphic DNA (RAPD). The study also hopes to determine the genetic similarities and differences among the individuals of the selected plant population within the agro ecological zones of northern Nigeria.Dhillion et al. (2007) utilized RAPD markers to assess the genetic variety in Azadirachtaindica population from various eco-geological locale of India.

\section{Materials and Methods \\ 2.1Plant Sample Collection}

The study occurred between February and July of 2019. The research randomly targeted 27 individual Neem tree species scattered within the 4 agro-ecological zones of Northern Nigeria (Figure 1). The plant samples were not obtained from the wild; they were obtained from within cultivated or built environment. This is because the plant is very common either as wind break, aesthetic, horticultural or for phytomedicinal purposes. Formal identification of the samples was made possible with assistance from Plant Taxonomy and Herbarium Unit of the Department of Plant Biology and Biotechnology, University of Benin, Benin City, and the Department of Botany, Federal University, Lafia, Nassarawa State, Nigeria. Care was taken to ensure that tree species of interest were not sampled within a single, but a wider location in so far as they represent designated ecological zones of interest.

\subsection{Sample collection and storage}

For RAPD analysis, seeds were used. Seeds from mature fruits were collected from each tree as described by Singh et al. (2005). Selection of tree for sample collection was based on the following conditions; that the tree should have a visible bole of not less than $3 \mathrm{~m}$, a basal girth of not less than $50 \mathrm{~cm}$ and must show evidence of fruiting. Seed samples were immediately covered with aluminium foil paper and placed in ice packed coolers. The seeds were then labeled according to geographic locations of trees as provided on Table 1.

\subsection{RAPD Analysis.}

In order to obtain clear reproducible amplification products, different preliminary experiments were carried out in which a number of factors were optimized. These factors included PCR annealing temperatures and concentration of each of the template DNA (Kumari and Thakur, 2014). A total of 9 random DNA oligonucleotides were independently used in the PCR reaction (Table 2). PCR was performed with $10 \mu$ volumes using Thermo Fisher Scientific PCR mix. The final concentrations were as follows: $1 \mathrm{X}$ Taq buffer, 2.5 $\mathrm{mM}, \mathrm{MgCl}_{2}, 0.32 \mathrm{mM}$, dNTP mixture, $0.25 \mu \mathrm{M}$ for each primer, $0.5 \mathrm{U}$ Taq polymerase and 
10 ng genomic DNA. All reactions were performed using a Wagetech Projects Master Cycler (Eppendorf, Hamburg, Germany) with an initial denaturing cycle of $5 \mathrm{~min}$ at $95{ }^{\circ} \mathrm{C}, 40$ cycles of $30 \mathrm{~s}$ at $93{ }^{\circ} \mathrm{C}, 1 \mathrm{~min}$ at $43{ }^{\circ} \mathrm{C}, 1 \mathrm{~min}$ at $72{ }^{\circ} \mathrm{C}$, and a final extension cycle of $10 \mathrm{~min}$ at $72{ }^{\circ} \mathrm{C}$. The pure DNA was stored at $-20^{\circ} \mathrm{C}$.

\subsection{Agarose Gel Electrophoresis.}

The PCR products were visualized using ethidium bromide dye in $2 \%$ agarose gels. The gel matrix was prepared following the protocol of Ihase et al. (2014). The solution was then poured on a gel tray with a comb inserted in it. Using a micro pipette, $1 \mu$ l of loading dye was added to $9 \mu \mathrm{l}$ of the final product and the mixture was loaded into the wells. The tank was connected to a power source at $90 \mathrm{~V}$ for 60 mins. The gel photograph was taken using a digital camera.

\section{Data Analysis}

The DNA bands were counted and fragment sizes compared with those of the DNA Ladder. The bands were scored and used for genotyping. The presence or absence of each DNA band was treated as a binary character in a data matrix (coded 1 and 0 , respectively) to calculate genetic similarity and to predict variations among the fruit forms. The genetic distance between the three fruit forms was calculated using GeneAlEx 6.502 software which was used to construct a dendogram on MEGA 7.0.21 software (Kumar et al. 2016).

\subsection{RESULTS}

Nine (09) random primers were obtained and screened for responsiveness to the neem genome. This was done to select the most suitable primer for the RAPD study. Only primers OPA-02, OPA-03, OPA-15 and OPA-19 turned out to be responsive. Primers OPA-04, OPA05, OPA 6, and OPA-11 were not responsive. They did not amplify any region of the neem genome tested. Information of the random primers used for this study are presented in Table 2. RAPD primers variations in the study of genetic diversity of Neem tree has been presented on Table 3. Among the primers used in the study, Primer OPA-15 was most effective. Mean number of effective alleles ranged from $1.095-1.625$. OPA-15 had the highest diversity index compared to others used in the study. Expected Heterozygosity ranged from $0.088-$ 0.405. heterozygocity was higher with Primer OPA-15.

\section{Preliminary gels from responsive primers}

Using Primer OPA-02, visible bands were reported in samples collected from Abuja-2, Adamawa-3, Benue-1, Benue-2, Borno-3, Sokoto-3 and Yobe-2 (Figure 2). The implication is that among the samples collected from Abuja, one was genetically distinct from the other. This was similar to those collected in Adamawa, Borno, Benue, Sokoto and Yobe States respectively.Using Primer OPA-03 (Figure 3), amplifications were recorded for samples collected from Abuja-1, Abuja-2, Abuja-3, Kaduna-1,. Kaduna-2, Borno-3, Nassarawa-1, Nassarawa2, Yobe-1, Yobe-2, Yobe-3. Using Primer OPA-02, samples collected from Yobe State were of similar genetic identity as their banding patterns were similar. They also had similar amplifications with samples collected from Borno State.

Gels of responsive Primer OPA-04 showed amplifications for all Abuja samples, Kaduna-1 and Kaduna-2, Borno-2 and Borno-3, Nasarawa-1, as well as all samples from Yobe State 
(Figure 4). These identities had distinct banding patterns indicating genetic dissimilarities. More than $80 \%$ of the samples collected showed amplified bands using Primer OPA-15, with majorly dissimilar characteristics (Figure 5). Samples from Borno and Yobe States had similar banding patterns, indicating possible genetic identities (Figure 6).

In the Abuja samples, 20 bands were observed; all these Different Bands had a Frequency $\geq$ $5 \%$ (Table 4). However, the Borno samples had the highest number of bands (38). Of the 38 bands in the Borno samples, 20 were locally common bands found in 50\% or fewer populations. Mean number of available alleles ranged from 0.154 (Kano samples) to 1.949 (Borno samples) (Table 5). In spite of this difference, number of effective alleles between these two locations were comparable $(1.046$ - 1.686). Table 6 shows the percentage polymorphism of RAPD markers across the nine locations in the study. Percentage polymorphism was highest among the Borno samples (97.44\%), compared to samples in Yobe State with no polymorphism. Mean percentage polymorphism was $39.60 \%$.

Nei's pairwise genetic distance and genetic identity among nine populations have been presented (Table 7). The Yobe samples were more genetically distant from Benue samples than they were when compared with other locations. In terms of genetic identity, the Sokoto tree were most likely more identical to samples located in Borno State.

From the Analysis of molecular variance using RAPD markers among locations, it was recorded that estimated variance was more within the populations than among the populations (Table 8). Figure 7a-i shows the test tree at various sampling locations. 


\subsection{Discussion}

The findings of this study corroborate previous reports of the neem tree's economic importance to Nigerians' socioeconomic lives, especially in the north (see Table 1) (Uko and Kamalu 2001; Lale 2002; Uko and Kamalu 2001; Uko and Kamalu 2001; Uko The tree is also adaptable to a wide range of climatic and topographic conditions, thriving in sandy, stony shallow soil sand as well as soils with hard calcareous or clay pan, according to the report. The neem tree just requires a little water and a lot of sunlight to thrive (Ogbuewu, et al., 2010). The $\mathrm{pH}$ differences between soil depths were minor. Organic carbon levels were high $(1.61-1.97$ percent $)$ and magnesium levels were moderate $(2.05-2.82 \mathrm{Cmole} / \mathrm{kg})$, according to Metson (1961), regardless of location in the North East or soil depth. Similarly, nitrite levels $(0.01-0.04 \mathrm{ppm})$ were similar regardless of position and depth (see Table 5). Iron content, on the other hand, varied, with the lowest concentration in Borno (BN-BK-2) $(2.29-5.78 \mathrm{ppm})$. Though iron is classified as a micronutrient since only small amounts are needed for normal plant development, Borno (BN-BK-2) had the lowest iron concentration, ranging from 2.29 to $5.78 \mathrm{ppm}$. The evaluation of genetic diversity of any species is very important for their conservation and gene manipulation (Khan et al. 2012).

Neem is thought to have a high cross-pollination rate. There have been records of interprovenance differences in morphological and physiological characteristics in neem. To determine the degree and/or form of genetic (DNA) variation in neem, a powerful molecular technique must be used. The genetic variation of neem ecotypes has recently been determined using molecular techniques such as AFLP, RAPD, ISSR, and RFLP banding patterns (Kota et al. 2006). To extract high-quality genomic DNA, 27 neem samples from Northern Nigeria were used.Nine (09) random primers were obtained and screened for responsiveness to the neem genome, with 5 of them proving to be responsive (Table 2). Because of its ability to search across regions of the genome, RAPD analysis is well suited for phylogenetic studies at the species level. Primers used in RAPD studies are usually random (Kumari and Thakur 2014), necessitating the acquisition of a large number of primers for screening. This increases the likelihood of finding primers that answer. Dhillon et al. (2007) investigated the degree and distribution of genetic diversity in A. indica from different eco-geographical regions of the world using RAPD markers and found that they were reliable.

The genetic similarities and variations among the neem samples examined varied significantly from one primer to the next. Variations in RAPD primers were discovered in the study of Neem tree genetic diversity. Primer OPA-15 was the most powerful of the primers used in the analysis. The average number of successful alleles was 1.095-1.625. When compared to the other samples included in the analysis, OPA-15 had the highest diversity index. Heterozygosity was expected to be between 0.088 and 0.405 . Primer OPA-15 increased heterozygozity.

Dhillion et al. (2007) used RAPD molecular markers to assess genetic diversity in Azadirachtaindicapopulations from various eco-geographical regions of India. A total of 40 decamer primers were used, and 24 of them resulted in polymorphic banding patterns. A total of 152 distinct DNA bands could be reliably collected, with 104 (68.4\%) of them being polymorphic. To classify genetic relationships, polymorphisms were graded and used in band-sharing research. All 36 populations were grouped into two major groups using cluster analysis based on Jaccard's similarity coefficient and UPGMA.

Using Primer OPA-02, visible bands were reported in samples collected from Abuja-2, Adamawa-3, Benue-1, Benue-2, Borno-3, Sokoto-3 and Yobe-2 (Figure 2). The implication 
is that among the samples collected from Abuja, one was genetically distinct from the other. This was similar to those collected in Adamawa, Borno, Benue, Sokoto and Yobe States respectively. Findings indicated that samples collected from Abuja were genetically distinct from one another even though they are collected from the same state. This however doesn't agree with Singh et al. (2005) who analyzed the RAPD to access genetic divergence among 29 neem accessions collected from two agro-ecological regions of India (11 agro-climatic sub-zones) and found out that 14 were polymorphic, generating a total of 3 amplifications products with an average of 5.21 products per polymorphic primer and estimated gene diversity of 0.49 .

Contrary observation was seen using Primer OPA-03, samples collected from Yobe State were of similar genetic identity as their banding patterns were similar (Figure 4). Figure 5 and 5 also showed majorly dissimilar characteristics where Primer OPA-15 had more than $80 \%$ of the samples collected showed amplified bands, with majorly dissimilar characteristics.

Furthermore, a striking result is that they also had similar amplifications with samples collected from Borno State using both OPA-03 and OPA-15 (plates 3and5) indicating possible genetic identities. Therefore the high percentage of similar banding profile generated in this study is not surprising but expected due to the close proximity between the two states. Also, samples from Born and Yobe had broader leaf size and had delayed seed emergence (see Table 18). Farooqui et al. (1998) reported RAPD profiles of 17 accessions of neem from India were generated using 49 random DNA primers. The dendogram of similarities amongst the RAPD profiles suggested that there was less variation than expected within neem from India. In addition, the pattern of RAPD similarities obtained did not correspond to the pattern of geographical variation in neem. This result is not unusual when assessing provenance variation using molecular methods, and the use of additional genetic analyses would have assisted the interpretation of the results.

In the Abuja samples, 20 bands were observed; all these different bands had a Frequency $\geq$ $5 \%$ (Table 5). However, the Borno samples had the highest number of bands (38). Of the 38 bands in the Borno samples, 20 were locally common bands found in $50 \%$ or fewer populations.

Indication of significant polymorphism was reported in the study. Percentage polymorphism was highest among the Borno samples (97.44\%), compared to samples in Yobe State with no polymorphism. Mean percentage polymorphism was $39.60 \%$. Mean number of available alleles ranged from 0.154 (Kano samples) to 1.949 (Borno samples). In spite of this difference, number of effective alleles between these two locations were comparable (1.046 1.686).This is an indication that there is an allelic similarities between Borno and Kano samples. It is most likely that the parent plants were derived from the same mother plant, several years ago. From the Analysis of molecular variance using RAPD markers among locations, it was recorded that estimated variance was more within the populations than among the populations (Table 8). This however does not collaborate with Farooqui et al. (1998) who reported RAPD profiles of 17 accessions of neem from India were generated using 49 random DNA primers. The dendogram of similarities amongst the RAPD profiles suggested that there was less variation than expected within neem from India.

Application of PCA tool and multivariate statistical analysis provide useful means to estimate morphological diversity within and between germplasm collections. The distinctive nature of Abuja samples among other samples (see Fig. 6and7) collaborates withMaletsemaet al. (2019). The genetic relatedness is useful for selection of parental lines for hybridization in 
crop improvement. Among the locations, Adamawa, Nasarawa and Kaduna populations were clustered. This may indicate likely genetic identities (see Fig. 8). The genetic relatedness is useful for selection of parental lines for hybridization in crop improvement Dosso-Aminon et al. (2015). Abuja tree samples were separated from the population (see Fig. 9) in terms of phylogeny. Maletsema et al. 2019 working on sorghum accessions reported that Accession 10 collected was distantly related with the other accessions which disagrees with the present findings. The diversity observed among the neem samples could be useful in improvement of neem for various traits (Updhyaya et al. 2010).

\section{Conclusion}

The study thus showed genetic dissimilarities among the trees investigated. These genetic disparities as observed through RAPD analysesexisted across the ecological zones.It is indeed unclear if this was caused by plant distribution, soil conditions, weather, or atmosphere. These plants, on the other hand, clearly differed in their ecotypes. The recorded potential for genetic diversity is a significant attribute for ecosystem management and germplasm conservation, given the economic value of this tree. Despite the molecular diversity found among neem trees in Northern Nigeria, it had no effect on their economic importance or significance in one area compared to another.

\section{Funding}

This study, which was part of a Ph.D. research study by BPM and co-supervised by GOA, BI and BOE, was funded by the Nigeria Tertiary Trust Fund (TETFund) Staff Development Grant 2019/2020. Funds covered RAPD analyses, sample collection and travels.

\section{Authors' contributions}

The study was designed by GOA and BI, and supervised by GOA, BI, and BOE. The field work was carried out by BPM. Data collection and interpretation was by GOA, BI, BOE, and BPM. Statistical analysis of data was by BI. All authors read, revised and approved the final manuscript.

\section{Conflicts of Interest}

The authors declare no conflicts of interest

\section{Acknowledgements}

The authors are grateful to the Tertiary Education Trust Fund (TETFund), Nigeria, for providing grants for the study. The assistance and constructive criticisms of Prof. J.K. Mensah of the Department of Botany, Ambrose Alli University, Ekpoma, Nigeria, are highly appreciated.

\section{References}

Allard RW, Principles of plant breeding. 2nd ed, John Wiley \& Sons, New York 254p, 1999.

APHA, Standard method for the examination of water and waste water. American Public Health Association, Washington DC. 256p, 1985. 
Bray RH, Kurtz LT, Soil chemical analysis. Soil Science 59,39-45, 1985 a.

Bray RH, Kurtz LT, Determination of total organic and available form of phosphorus in soils. Soil Science 59,45-49, 1945 b.

Dhillon RS, Mohapatra T, Singh S, Boora KS, Singh K (2007). Assessment of genetic diversity in Azadirachtaindicabased on DNA fingerprinting, Indian Journal of Biotechnology $6,519-524$

Dossou-Aminon I, Yêyinou Loko L, Adjatin A, Ewédjè B, Dansi A, Rakshit S, Akpagana K, (2015) Genetic Divergence in Northern Benin sorghum (Sorghum bicolor L. Moench) landraces as revealed by agro-morphological traits and selection of candidates genotypes. Science World Journal $1-10$

Farooqui N, Ranade S, Sane P (1998). RAPD profile variation amongst provenances of neem. Biochemical and Molecular Biology International 45, 931-939

Jindal S, Vir S, Pancholy A (1999). Variability and associations for seed yield, oil content and tree morphological traits in neem (Azadirachta indica) Journal of Tropical Forest Science $11,320-322$

Johnson HW, Robinson HF, Comstock RE (1955). Estimation of genetic and environmental variability in Soybeans. Agronomy Journal 47, $314-318$.

Ketkar C, Ketkar M (1995). Neem seed crush and deoild cake as manure and as nitrification inhibitors. The Neem Tree Azadirachta indica A. Juss. And other Meliaceous plants, ed. H. schmutterer. 531-540.

Khan S, Guo L, Maimaiti Y, Mijit M, Qui D (2012). Entomopathogenic fungi as microbial biocontrol agent. Molecular Plant Breeding 3(7), 3-6.

Kota S, Rao N, Chary P (2006). In vitro response of select regions of Azadirachta indica. Curricular Science 91(6), 770-776

Koul O, Isman M.B, Ketkar C.M (1990). Properties and uses of neem (Azadirachtaindica). Canadian Journal of Botany68, 1-11

Kumar S, Stecher G, and Tamura K (2016). MEGA7, Molecular Evolutionary Genetics Analysis version 7. Molecular Biology and Evolution33, 1870 - 1874.

Kumaran K, Surendran C, Rai R (1993). Variation studies and heritable components of seed parameters in neem (Azadirachta indica A. Juss.) Proceedings of the World Neem conference, (pp. 167-173.) Banglore.

Kumari N, Thakur S K (2014). Randomly Amplified Polymorphic DNA - A brief review. American Journal of Animal and Veterinary Sciences 9(1), 6-13.

Lale N, Mustapha A, Efficacy and acceptability of neem (Azadirachta indica A. Juss.) seed oil and pirimiphos-methyl applied in three storage devices for the control of Callosobruchus maculates (F.) (Caleoptera, Bruchidae). Emir J Food Agr 310-315, 2000. 
Maletsema A M, Hussein SLM (2019). Nemera S, Genetic variability, heritability and genetic gain for quantitative traits in South African sorghum genotypes. Australian Journal of Crop Science 13(1), 1-10.

Maniee M, Kahrizi D, Mohammadi R (2009) Genetic variability of some morphophysiological traits in durum wheat (Triticum durum Desf.) Journal of applied Science 9(7), 1383-1387.

Metson AJ (1961). Methods of Chemical Analysis of Soil Survey Samples. Govt. Printers, Wellington, New Zealand. P 207.

Nelson DW, Sommers LE (1982). Total carbon, organic carbon and organic matter. In, Methods of soil analysis, Part 2. ASA/SSSA. Madison WI. 539-579pp.

Nwangburuka C, Denton O, Kehinde O, Ojo D, Popoola A (2012.). Genetic variability and heritability in cultivated okra [Abemoschus esculentus (L.) Moecnch]. Spanish Journal of Agricultural Resources 1, 123-129.

Ogbuewu I, Okoli I, Iloeje M(2010). Assessment of blood chemistry, weight gain and linear body measurements of pre-puberal buck rabbits fed different levels of Neem (Azadirachta indica A. Juss.) leaf meals. Chilean Journal of Agricultural Research 70(3), 515-520

Rathore M, Tripathi Y, Kumar S (1998). Inter-dependence of seed quality and protein content with reference to neem seeds from different origins. Annals of Agricultural and Biological Research 3, 133-138.

Rengasamy J, Reid J (1993). Root system modification of faba beans (Vicia faba L.), and its effects on crop performance. Field Crops Research 33(3), 197-215.

Rengasamy NP (1995).Azadirachta indica- A content of seeds of neem ecolypes in relation tp agro-ecological regions of India. Pesticides Research Journal 7,140-148.

Secande M, Groot SPC, Hoekstra FA, De Castro R, Bino RJ (1997). Cell cycle events in developing neem (Azadirachta indica) seeds, are they related to intermediate storage behaviour? Seed Science Research 7,161-168.

Singh, RP, Singh R, Malik, K,Randhawa GJ (2005).Assessment of genetic diversity and genetic relationships among 29 populations of Azadirachtaindica A. Juss. using RAPD markers, Genetic Resources and Crop Evolution 52, 285-292.

Uko O, Kamalu T (2001). The neem tree-uses and potentials. Nigerian Journal of Experimental Applied Biolology 2,223-229.

Upadhyay RK, Dwivedi P, Ahmad S (2010). Screening of antibacterial activity of six plant essential oils against pathogenic bacterial strains. Asian Journal of Medical Science 2(3),152158.

USDA (1998). Forest nursery practices in Southern United States. Foresta 1,106-146.

Veerendra H (1995). Variation studies in provenances of Azadirachta indica (the neem tree) Indian Forester 121 1053-1056. 
bioRxiv preprint doi: https://doi.org/10.1101/2021.11.22.469531; this version posted November 24, 2021. The copyright holder for this preprint (which was not certified by peer review) is the author/funder, who has granted bioRxiv a license to display the preprint in perpetuity. It is made available under aCC-BY 4.0 International license.

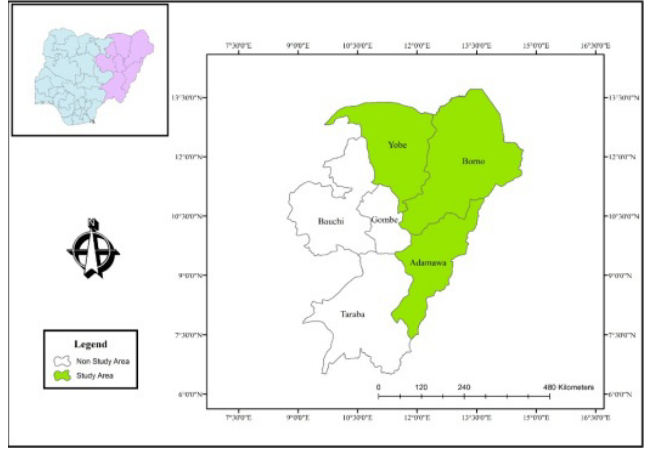

(a)

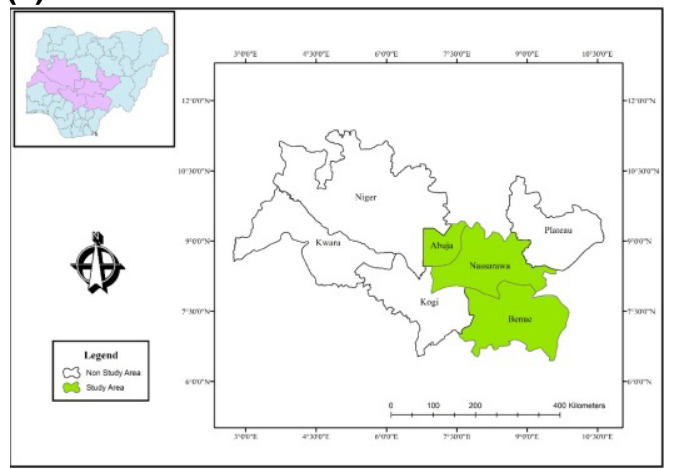

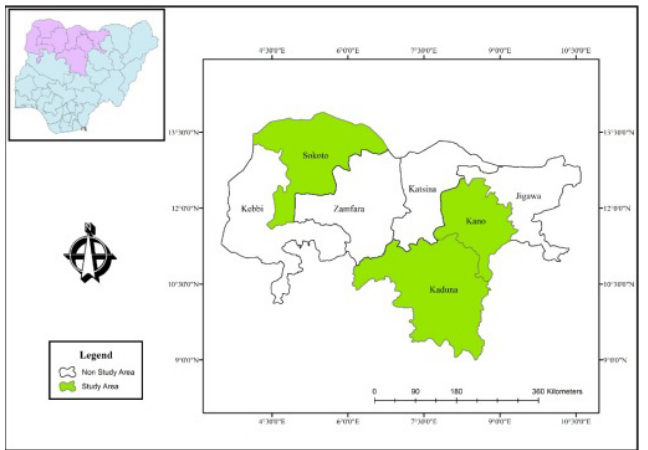

(b)

(c)

Figure 1: Map showing study area at the (a) North Eastern, (b) North West and the (c) North Central region of the country 
Table 1: Sample codes for collection of plant samples during the study

\begin{tabular}{|c|c|c|c|}
\hline Code & Plant physical location & State & Agro-ecological zone \\
\hline YB-BK-1 & $\begin{array}{l}\text { Along Malari motor park, Malari } \\
\text { ward, Damaturu. }\end{array}$ & Yobe & Sahel savanna \\
\hline YB-BK-2 & Potiskum cattle market & Yobe & Sahel savanna \\
\hline YB-BK-3 & $\begin{array}{l}\text { Federal University, Gashua. } \\
\text { Sabongari, Nguru-Gashua Road, } \\
\text { Damasak road, Gashua }\end{array}$ & Yobe & Sahel savanna \\
\hline AD-BK-1 & Federal college of education, Yola & Adamawa & Southern Guinea savanna \\
\hline AD-BK-2 & Emirs palace, Mubi & Adamawa & Southern Guinea savanna \\
\hline AD-BK-3 & College of Agriculture, Ganye & Adamawa & Southern Guinea savanna \\
\hline BN-BK-1 & E.Y.N Church, Wulari, Maiduguri & Borno & Sahel savanna \\
\hline BN-BK-2 & Army University, Biu & Borno & Sahel savanna \\
\hline $\mathrm{BN}-\mathrm{BK}-3$ & University of Maiduguri & Borno & Sahel savanna \\
\hline KN-BK-1 & GidanBuhari Road, T/Wada Kano & Kano & Sudan savanna \\
\hline KN-BK-2 & BUK, Kano state & Kano & Sudan savanna \\
\hline KN-BK-3 & Dala Orthopedic Hospital, Kano & Kano & Sudan savanna \\
\hline SK-BK-1 & $\begin{array}{l}\text { Usman Dan Fodio University, } \\
\text { Sokoto }\end{array}$ & Sokoto & Sudan savanna \\
\hline SK-BK-2 & $\begin{array}{l}\text { SaniDingyadi Sec. Sch. Farfaru, } \\
\text { Sokoto }\end{array}$ & Sokoto & Sudan savanna \\
\hline SK-BK-3 & Sokoto main market, Sokoto & Sokoto & Sudan savanna \\
\hline KD-BK-1 & Ahmadu Bello University, Zaria & Kaduna & Northern Guinea savanna \\
\hline KD-BK-2 & Sabo motor park, Kaduna & Kaduna & Northern Guinea savanna \\
\hline KD-BK-3 & Close to Stanbic IBTC & Kaduna & Northern Guinea savanna \\
\hline NS-BK-1 & $\begin{array}{l}\text { OBKi-1 opposite Nasarawa } \\
\text { Polytechnic, Lafia }\end{array}$ & Nasarawa & Southern Guinea savanna \\
\hline NS-BK-2 & $\begin{array}{l}\text { Hope academy secondary school, } \\
\text { Akwanga }\end{array}$ & Nasarawa & Southern Guinea savanna \\
\hline NS-BK-3 & Awe Motor Park, Awe LGA & Nasarawa & Southern Guinea savanna \\
\hline AJ-BK-1 & Lungi Barracks, Maitama Abuja. & Abuja & Derived savanna \\
\hline AJ-BK-2 & $\begin{array}{l}\text { MaBKilla Barracks, Asokoro } \\
\text { Abuja }\end{array}$ & Abuja & Derived savanna \\
\hline AJ-BK-3 & $\begin{array}{l}\text { Opposite State House Medical } \\
\text { Centre, Asokoro Abuja }\end{array}$ & Abuja & Derived savanna \\
\hline BN-BK-1 & University of Agriculture, Makurdi & Benue & Derived savanna \\
\hline BN-BK-2 & Benue State University, Makurdi & Benue & Derived savanna \\
\hline BN-BK-3 & Peace House, Gboko & Benue & Derived savanna \\
\hline
\end{tabular}


bioRxiv preprint doi: https://doi.org/10.1101/2021.11.22.469531; this version posted November 24,2021 . The copyright holder for this preprint (which was not certified by peer review) is the author/funder, who has granted bioRxiv a license to display the preprint in perpetuity. It is made available under aCC-BY 4.0 International license.

Table 2: Primer information on 9 primers for RAPD study

\begin{tabular}{lll}
\hline S/No & Primer name & Primer Sequence \\
\hline 1 & OPA-02 & 5' TGCCGAGCTG 3' \\
2 & OPA-03 & 5' AGTCAGCCAC 3' \\
3 & OPA-04 & 5' AATCGGGCTG 3' \\
4 & OPA-05 & 5' AGGGGTCTTG 3' \\
5 & OPA-07 & 5' GAAACGGGTG 3' \\
6 & OPA-11 & 5' CAATCGCCGT 3' \\
7 & OPA-17 & 5' GACCGCTTGT 3' \\
8 & OPA-19 & 5' CAAACGTCGG 3' \\
9 & OPA-15 & 5' TTCCGAACCC 3' \\
\hline
\end{tabular}

Table 2: Random primer screening.

\begin{tabular}{llll}
\hline S/No & Primer name & Primer Sequence & Response \\
\hline 1 & OPA-02 & 5' TGCCGAGCTG 3' & + \\
2 & OPA-03 & 5' AGTCAGCCAC 3' & + \\
3 & OPA-04 & 5' AATCGGGCTG 3, & + \\
4 & OPA-05 & 5' AGGGGTCTTG 3' & No response \\
5 & OPA-07 & 5' GAAACGGGTG 3' & - \\
6 & OPA-11 & 5, CAATCGCCGT 3, & No response \\
7 & OPA-17 & 5' GACCGCTTGT 3, & - \\
8 & OPA-19 & 5' CAAACGTCGG 3, & + \\
9 & OPA-15 & 5' TTCCGAACCC 3, & + \\
\hline
\end{tabular}


Table 3: RAPD primers variations in the study of genetic diversity of Neem tree

\begin{tabular}{|c|c|c|c|c|c|}
\hline Primers & $\mathrm{Na}$ & $\mathrm{Ne}$ & I & $\mathrm{He}$ & $\mathrm{uHe}$ \\
\hline OPA-04- 1 & 0.444 & 1.153 & 0.129 & 0.088 & 0.105 \\
\hline OPA-04- 2 & 0.556 & 1.095 & 0.106 & 0.067 & 0.080 \\
\hline OPA-04- 3 & 0.556 & 1.212 & 0.151 & 0.108 & 0.130 \\
\hline OPA-04- 4 & 1.000 & 1.307 & 0.257 & 0.175 & 0.210 \\
\hline OPA-04- 5 & 1.000 & 1.365 & 0.280 & 0.196 & 0.235 \\
\hline OPA-04- 6 & 1.000 & 1.307 & 0.257 & 0.175 & 0.210 \\
\hline OPA-04- 7 & 1.000 & 1.307 & 0.257 & 0.175 & 0.210 \\
\hline OPA-04- 8 & 0.667 & 1.201 & 0.182 & 0.121 & 0.145 \\
\hline OPA-04- 9 & 0.889 & 1.190 & 0.212 & 0.133 & 0.160 \\
\hline OPA-02-1 & 0.667 & 1.259 & 0.204 & 0.142 & 0.170 \\
\hline OPA-02-2 & 0.667 & 1.259 & 0.204 & 0.142 & 0.170 \\
\hline OPA-02-3 & 0.667 & 1.259 & 0.204 & 0.142 & 0.170 \\
\hline OPA-02-4 & 0.667 & 1.259 & 0.204 & 0.142 & 0.170 \\
\hline OPA-02-5 & 0.667 & 1.259 & 0.204 & 0.142 & 0.170 \\
\hline OPA-02-6 & 0.556 & 1.153 & 0.129 & 0.088 & 0.105 \\
\hline OPA-02-7 & 0.556 & 1.153 & 0.129 & 0.088 & 0.105 \\
\hline OPA-02-8 & 0.778 & 1.201 & 0.182 & 0.121 & 0.145 \\
\hline OPA-02-9 & 0.889 & 1.249 & 0.235 & 0.154 & 0.185 \\
\hline OPA-02-10 & 0.444 & 1.153 & 0.129 & 0.088 & 0.105 \\
\hline OPA-03-1 & 0.778 & 1.259 & 0.204 & 0.142 & 0.170 \\
\hline OPA-03-2 & 0.889 & 1.259 & 0.204 & 0.142 & 0.170 \\
\hline OPA-03-3 & 0.889 & 1.201 & 0.182 & 0.121 & 0.145 \\
\hline OPA-03-4 & 0.889 & 1.201 & 0.182 & 0.121 & 0.145 \\
\hline OPA-03-5 & 1.000 & 1.307 & 0.257 & 0.175 & 0.210 \\
\hline OPA-03-6 & 1.000 & 1.249 & 0.235 & 0.154 & 0.185 \\
\hline OPA-03-7 & 1.000 & 1.307 & 0.257 & 0.175 & 0.210 \\
\hline OPA-03-8 & 0.778 & 1.201 & 0.182 & 0.121 & 0.145 \\
\hline OPA-15-1 & 0.667 & 1.201 & 0.182 & 0.121 & 0.145 \\
\hline OPA-15-2 & 0.667 & 1.201 & 0.182 & 0.121 & 0.145 \\
\hline OPA-15-3 & 0.889 & 1.249 & 0.235 & 0.154 & 0.185 \\
\hline OPA-15-4 & 1.333 & 1.402 & 0.363 & 0.242 & 0.290 \\
\hline OPA-15-5 & 1.778 & 1.614 & 0.515 & 0.350 & 0.420 \\
\hline OPA-15-6 & 1.667 & 1.566 & 0.462 & 0.317 & 0.380 \\
\hline OPA-15-7 & 1.667 & 1.625 & 0.484 & 0.338 & 0.405 \\
\hline OPA-19-1 & 0.778 & 1.201 & 0.182 & 0.121 & 0.145 \\
\hline OPA-19-2 & 0.889 & 1.259 & 0.204 & 0.142 & 0.170 \\
\hline OPA-19-3 & 0.889 & 1.259 & 0.204 & 0.142 & 0.170 \\
\hline OPA-19-4 & 1.000 & 1.307 & 0.257 & 0.175 & 0.210 \\
\hline OPA-19-5 & 1.000 & 1.307 & 0.257 & 0.175 & 0.210 \\
\hline Grand mean & 0.875 & 1.270 & 0.228 & 0.155 & 0.186 \\
\hline
\end{tabular}

Na $=$ No. of different alleles; $N e=$ No. of effective alleles; $I=$ Shannon's Information Index;

$H e=$ Expected Heterozygosity; $u H e=$ Unbiased Expected Heterozygosity 

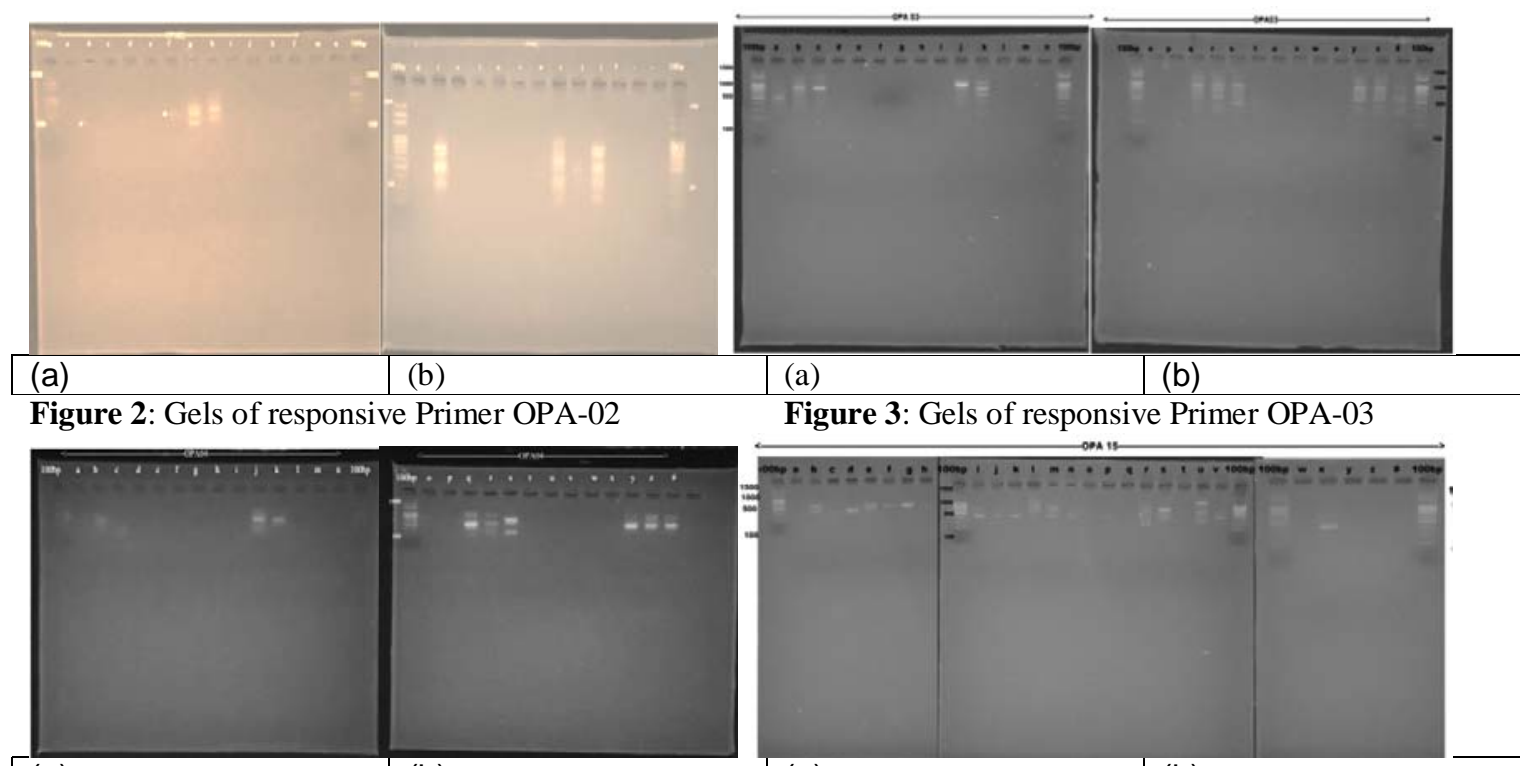

(a)

(b)

Figure 3: Gels of responsive Primer OPA-03

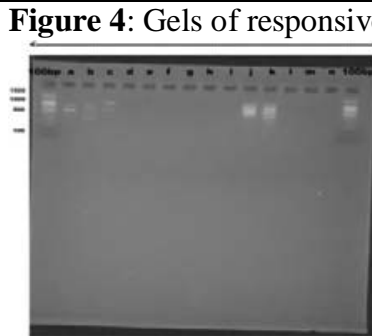

(a)

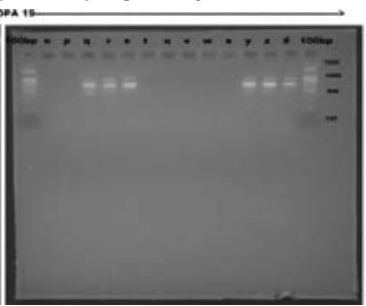

(a)

(b)

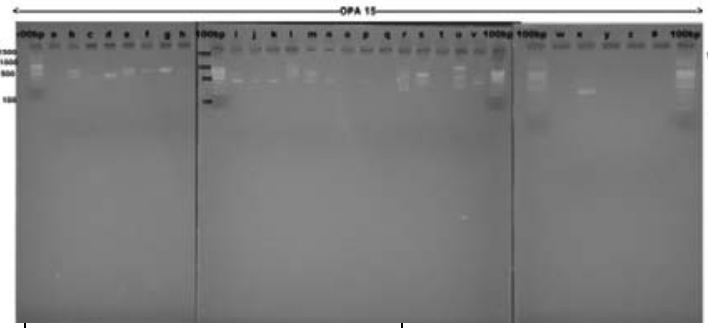

Figure 5: Gels of responsive Primer OPA-15

Figure 6: Gels of responsive Primer OPA-19

Abuja 2- b, Abuja 3- c; Adamawa 1- d, Adamawa 2- e, Adamawa 3- f; Benue 1- g, Benue 2h, Benue 3- I; Kaduna 1- j, Kaduna 2- k, Kaduna 3- L; Kano 1- m, Kano 2- n, Kano 3- O; Borno 1- p, Borno 2- q, Borno 3- r; Nasarawa 1- s, Nassarawa 2- t, Nassarawa 3- u; Sokoto 1$\mathrm{v}$, Sokoto-2; w, Sokoto $3 \mathrm{x}$; Yobe 1- y, Yobe 2- z, Yobe 3- \#

Table 4: Amplified bands detected with thirty-nine primers in Neem tree species across nine states in Nigeria (Primer OPA-15)

\begin{tabular}{llllllllll}
\hline Population & Abuja & Adamawa & Benue & Kaduna & Kano & Borno & Nasarawa & Sokoto & Yobe \\
\hline No. Bands & 20 & 6 & 13 & 29 & 3 & 38 & 25 & 15 & 19 \\
No. Bands Freq. $>=5 \%$ & 20 & 6 & 13 & 29 & 3 & 38 & 25 & 15 & 19 \\
No. Private Bands & 0 & 0 & 0 & 0 & 0 & 0 & 0 & 0 & 0 \\
No. LComm Bands $(<=25 \%)$ & 0 & 0 & 0 & 1 & 0 & 2 & 0 & 1 & 0 \\
No. LComm Bands $(<=50 \%)$ & 3 & 2 & 9 & 11 & 0 & 20 & 7 & 11 & 5 \\
Mean He & 0.144 & 0.061 & 0.143 & 0.261 & 0.028 & 0.389 & 0.221 & 0.145 & 0.000 \\
SE of Mean He & 0.031 & 0.024 & 0.034 & 0.031 & 0.016 & 0.018 & 0.029 & 0.036 & 0.000 \\
Mean uHe & 0.173 & 0.073 & 0.172 & 0.313 & 0.033 & 0.466 & 0.265 & 0.174 & 0.000 \\
SE of Mean uHe & 0.037 & 0.029 & 0.041 & 0.037 & 0.019 & 0.022 & 0.035 & 0.043 & 0.000 \\
\hline
\end{tabular}

Key
No. Bands $=$ No. of Different Bands

No. Bands Freq. $>=5 \%=$ No. of Different Bands with a Frequency $>=5 \%$

No. Bands Freq. $>=5 \%=$ No. of Different Bands with a Frequency
No. Private Bands $=$ No. of Bands Unique to a Single Population

No. Private Bands $=$ No. of Bands Unique to a Single Population
No. LComm Bands $(<=25 \%)=$ No. of Locally Common Bands (Freq $>=5 \%$ ) Found in $25 \%$ or Fewer Populations

No. LComm Bands $(<=25 \%)=$ No. of Locally Common Bands (Freq. $>=5 \%$ ) Found in $25 \%$ or Fewer Population
No. LComm Bands $(<=50 \%)=$ No. of Locally Common Bands (Freq. $>=5 \%$ ) Found in $50 \%$ or Fewer Populations No. LComm Bands $(<=50 \%)=$ No. of Locall

$\mathrm{He}=$ Expected Heterozygosity $=2 * \mathrm{p} * \mathrm{q}$
$\mathrm{uHe}=$ Unbiased Expected Heterozygosity $=(2 \mathrm{~N} /(2 \mathrm{~N}-1)) * \mathrm{He}$

Where for Diploid Binary data and assuming Hardy-Weinberg Equilibrium, $\mathrm{q}=(1-\text { Band Freq. })^{\wedge} 0.5$ and $\mathrm{p}=1-\mathrm{q}$. 
Table 5: Mean Biodiversity Statistics within Populations (Mean \pm SEM)

\begin{tabular}{llllll}
\hline Population & $\mathrm{Na}$ & $\mathrm{Ne}$ & $\mathrm{I}$ & $\mathrm{He}$ & $\mathrm{uHe}$ \\
\hline Abuja & $0.897 \pm 0.151$ & $1.245 \pm 0.057$ & $0.215 \pm 0.045$ & $0.144 \pm 0.031$ & $0.173 \pm 0.037$ \\
Adamawa & $0.308 \pm 0.117$ & $1.106 \pm 0.044$ & $0.089 \pm 0.035$ & $0.061 \pm 0.024$ & $0.073 \pm 0.029$ \\
Benue & $0.667 \pm 0.153$ & $1.264 \pm 0.065$ & $0.206 \pm 0.048$ & $0.143 \pm 0.034$ & $0.172 \pm 0.041$ \\
Kaduna & $1.436 \pm 0.141$ & $1.444 \pm 0.059$ & $0.388 \pm 0.044$ & $0.261 \pm 0.031$ & $0.313 \pm 0.037$ \\
Kano & $0.154 \pm 0.086$ & $1.046 \pm 0.028$ & $0.042 \pm 0.024$ & $0.028 \pm 0.016$ & $0.033 \pm 0.019$ \\
Borno & $1.949 \pm 0.051$ & $1.686 \pm 0.046$ & $0.569 \pm 0.022$ & $0.389 \pm 0.018$ & $0.466 \pm 0.022$ \\
Nasarawa & $1.282 \pm 0.156$ & $1.355 \pm 0.052$ & $0.337 \pm 0.042$ & $0.221 \pm 0.029$ & $0.265 \pm 0.035$ \\
Sokoto & $0.692 \pm 0.148$ & $1.28 \pm 0.069$ & $0.204 \pm 0.05$ & $0.145 \pm 0.036$ & $0.174 \pm 0.043$ \\
Yobe & $0.487 \pm 0.081$ & $1 \pm 0$ & 0 & 0 & 0 \\
\hline
\end{tabular}

$\mathrm{Na}=$ No. of different alleles; Ne = No. of effective alleles; I = Shannon's Information Index; He = Expected Heterozygosity; $\mathrm{uHe}=$ Unbiased Expected Heterozygosity

Table 6. Percentage polymorphism of RAPD markers across nine locations in Nigeria

\begin{tabular}{ll}
\hline Population & Polymorphism (\%) \\
\hline Abuja & 38.46 \\
Adamawa & 15.38 \\
Benue & 33.33 \\
Kaduna & 69.23 \\
Kano & 7.69 \\
Borno & 97.44 \\
Nasarawa & 64.10 \\
Sokoto & 30.77 \\
Yobe & 0.00 \\
\hline Mean & 39.60 \\
\hline
\end{tabular}

Table 7. Nei's pairwise genetic distance (below the diagonal) and genetic identity (above the diagonal) among nine populations

\begin{tabular}{llllllllll}
\hline Location & Abuja & Adamawa & Benue & Kaduna & Kano & Borno & Nasarawa & Sokoto & Yobe \\
\hline Abuja & & 0.825 & 0.771 & 0.872 & 0.832 & 0.896 & 0.860 & 0.685 & 0.732 \\
Adamawa & 0.192 & & 0.960 & 0.908 & 0.994 & 0.890 & 0.965 & 0.890 & 0.481 \\
Benue & 0.260 & 0.040 & & 0.832 & 0.957 & 0.867 & 0.916 & 0.957 & 0.428 \\
Kaduna & 0.137 & 0.097 & 0.184 & & 0.904 & 0.927 & 0.928 & 0.763 & 0.675 \\
Kano & 0.184 & 0.006 & 0.044 & 0.100 & & 0.896 & 0.962 & 0.873 & 0.500 \\
Borno & 0.109 & 0.117 & 0.143 & 0.076 & 0.110 & & 0.924 & 0.978 & 0.754 \\
Nasarawa & 0.151 & 0.036 & 0.088 & 0.075 & 0.039 & 0.080 & & 0.834 & 0.587 \\
Sokoto & 0.378 & 0.117 & 0.044 & 0.271 & 0.135 & 0.226 & 0.182 & & 0.337 \\
Yobe & 0.312 & 0.732 & 0.848 & 0.392 & 0.694 & 0.283 & 0.532 & 1.086 & \\
\hline
\end{tabular}


bioRxiv preprint doi: https://doi.org/10.1101/2021.11.22.469531; this version posted November 24, 2021. The copyright holder for this preprint (which was not certified by peer review) is the author/funder, who has granted bioRxiv a license to display the preprint in perpetuity. It is made available under aCC-BY 4.0 International license.

Table 8. Analysis of molecular variance using RAPD markers among locations

\begin{tabular}{|c|c|c|c|c|c|}
\hline $\begin{array}{l}\text { Source of } \\
\text { variation }\end{array}$ & Df & SS & MS & $\begin{array}{l}\text { Estimated } \\
\text { Var. }\end{array}$ & Variance $(\%)$ \\
\hline $\begin{array}{l}\text { Among } \\
\text { populations }\end{array}$ & 8 & 106.370 & 13.296 & 2.716 & 35 \\
\hline $\begin{array}{l}\text { Within } \\
\text { populations } \\
\text { Total }\end{array}$ & $\begin{array}{l}18 \\
26\end{array}$ & $\begin{array}{l}92.667 \\
199.037\end{array}$ & 5.148 & $\begin{array}{l}5.148 \\
7.864\end{array}$ & $\begin{array}{l}65 \\
100\end{array}$ \\
\hline
\end{tabular}

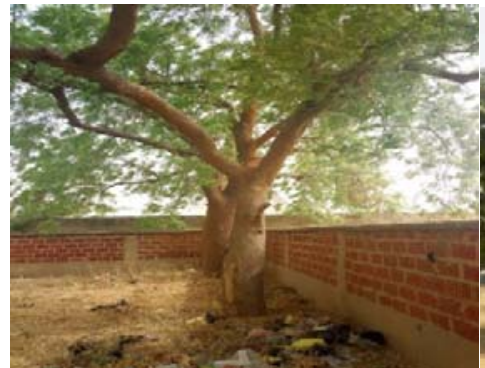

(a) Along Malari motor park, Malari ward, Damaturu, Yobe State

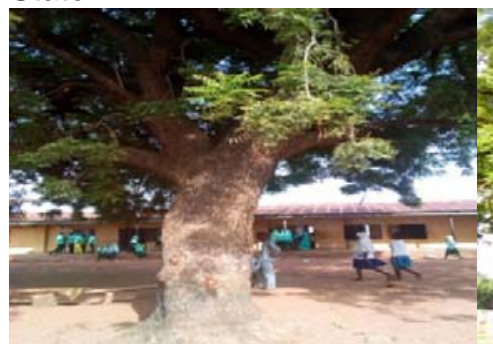

(d). Hope academy secondary school, Akwanga, Nassarawa State

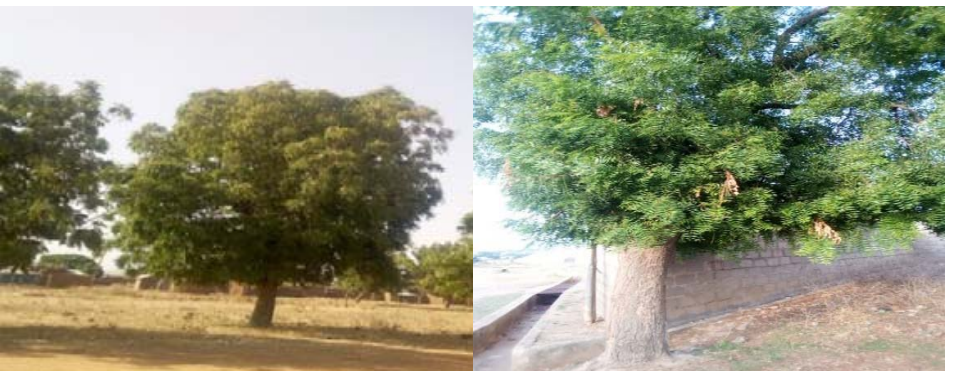

(b) Federal University, Gashua. Sabongari, Nguru-Gashua Road, Damasak road, Gashua (c) Emirs palace, Mubi, Adamawa State

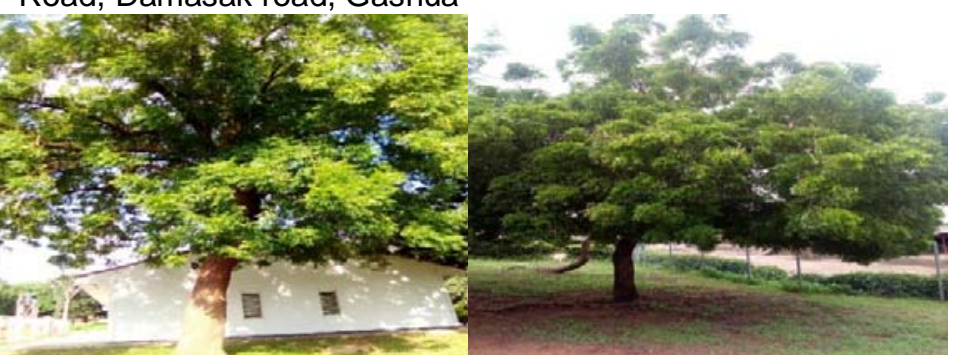
(e) Mambilla Barracks, Asokoro
(f) University of Agriculture,

Abuja Makurdi, Benue State

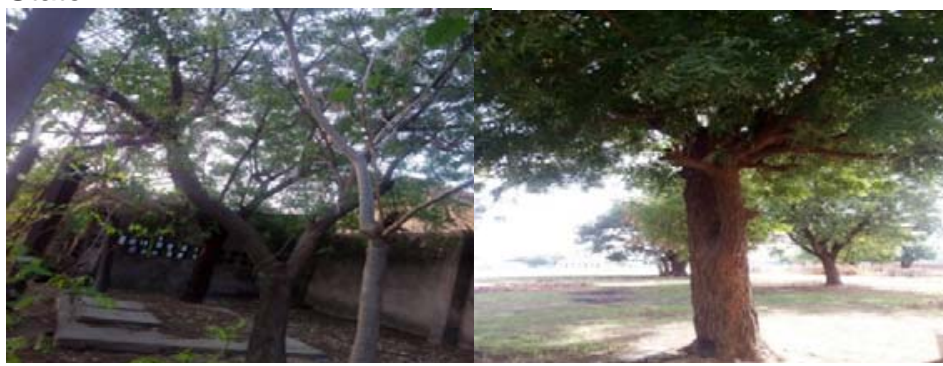

(g) Dala Orthopedic Hospital, Kano (h) Potiskum cattle market, Yobe State

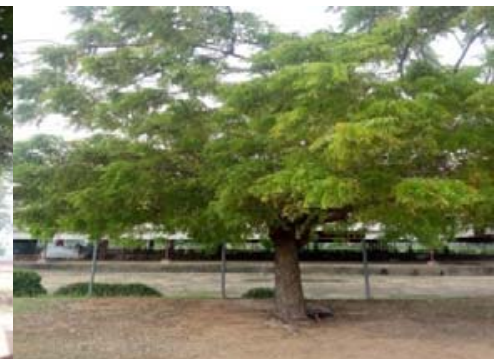

(i) Benue State University, Makurdi

\section{Figure 7(a-i): Test tree at various sampling locations}

Figure 8 shows Principal Component Analysis of samples. Results showed that Abuja 1 and Abuja 3 samples were distinct from the other groups which formed clusters. The UPGMA Phylogeny of Samples (Figure 9) also showed the district nature of the 2 Abuja tree samples. Among the locations, Adamawa, Nasarawa and Kaduna populations were clustered. This may indicate likely genetic identities (Figure 10). Again, as observed in Figures 4 and 5, the Abuja tree samples were separated from the population (Figure 11) in terms of phylogeny. 
bioRxiv preprint doi: https://doi.org/10.1101/2021.11.22.469531; this version posted November 24, 2021. The copyright holder for this preprint (which was not certified by peer review) is the author/funder, who has granted bioRxiv a license to display the preprint in perpetuity. It is made available under aCC-BY 4.0 International license.

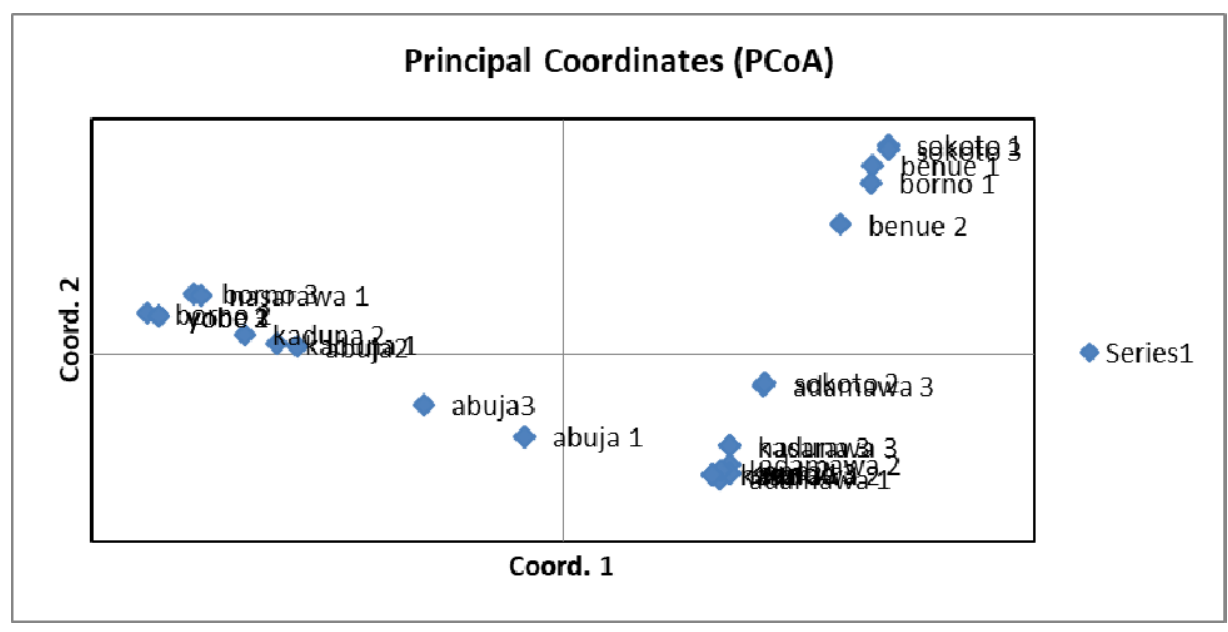

\begin{tabular}{|l|r|r|r|}
\hline \multicolumn{2}{|l|}{ Percentage of variation explained by the first 3 axes } & \\
\hline Axis & 1 & 2 & 3 \\
\hline$\%$ & 51.88 & 14.27 & 11.05 \\
\hline
\end{tabular}

Figure 8: Principal Component Analysis showing Sample Clustering

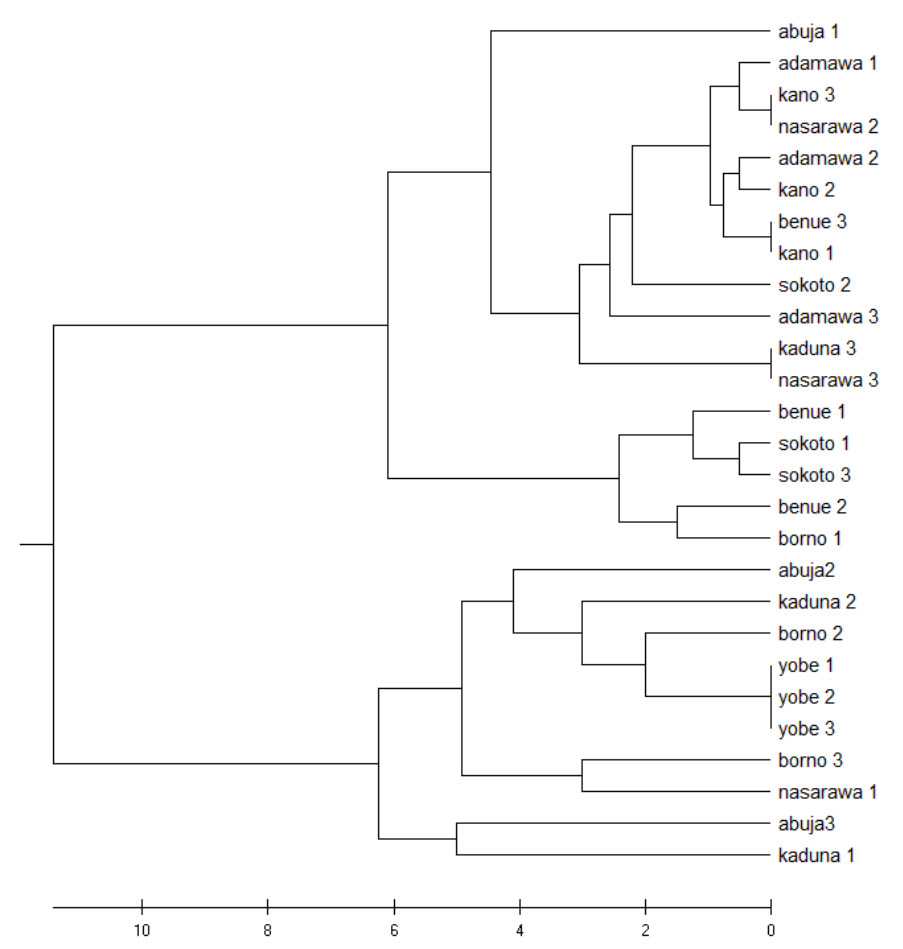

Figure 9: Unweighted pair group method with arithmetic mean phylogeny of samples 
bioRxiv preprint doi: https://doi.org/10.1101/2021.11.22.469531; this version posted November 24,2021 . The copyright holder for this preprint (which was not certified by peer review) is the author/funder, who has granted bioRxiv a license to display the preprint in perpetuity. It is made available under aCC-BY 4.0 International license.

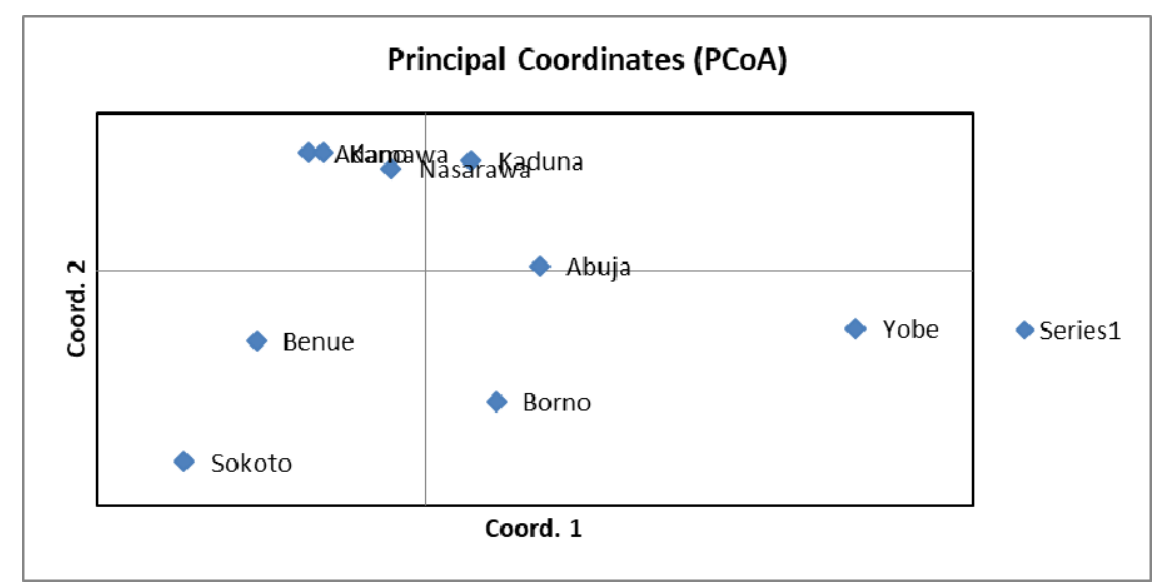

\begin{tabular}{|l|r|r|r|}
\hline \multicolumn{4}{|c|}{ Percentage of variation explained by the first 3 axes } \\
\hline Axis & 1 & 2 & 3 \\
\hline$\%$ & 77.48 & 8.55 & 7.32 \\
\hline
\end{tabular}

Figure 10: Principal component analyses showing population clustering

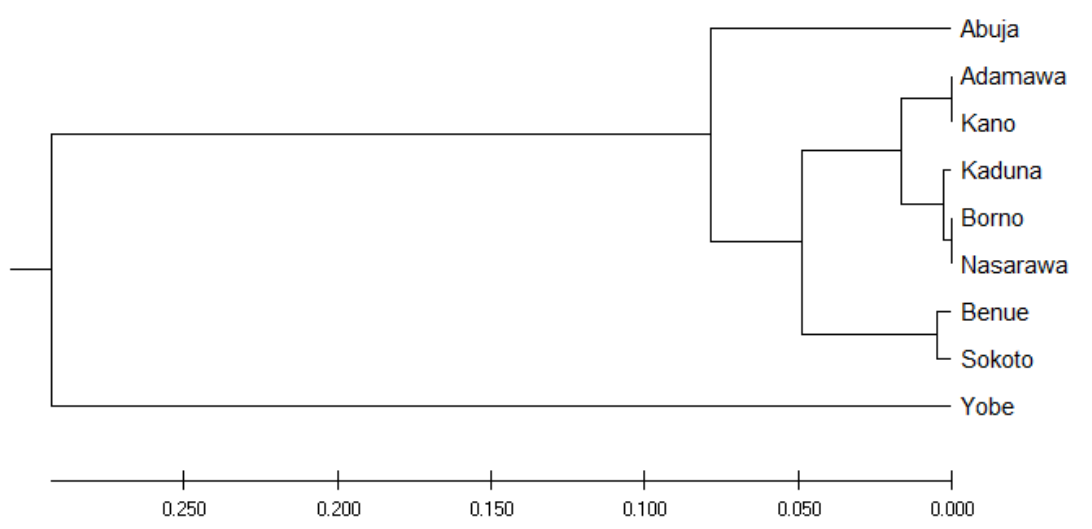

Figure 11: Unweighted pair group method with arithmetic mean phylogeny of populations 